\title{
Mixtures of Plant-Growth-Promoting Rhizobacteria Enhance Biological Control of Multiple Plant Diseases and Plant-Growth Promotion in the Presence of Pathogens
}

Ke Liu, John A. McInroy, Chia-Hui Hu, and Joseph W. Kloepper, ${ }^{\dagger}$ Department of Entomology and Plant Pathology, Auburn University, Auburn, AL 36849

\begin{abstract}
Several studies have shown that mixtures of plant-growth-promoting rhizobacteria (PGPR) could enhance biological control activity for multiple plant diseases through the mechanisms of induced systemic resistance or antagonism. Prior experiments showed that four individual PGPR strains-AP69 (Bacillus altitudinis), AP197 (B. velezensis), AP199 (B. velezensis), and AP298 (B. velezensis)—had broad-spectrum biocontrol activity via antagonism in growth chambers against two foliar bacterial pathogens (Xanthomonas axonopodis pv. vesicatoria and Pseudomonas syringae pv. tomato) and one of two tested soilborne fungal pathogens (Rhizoctonia solani and Pythium ultimum). Based on these findings, the

overall hypothesis of this study was that a mixture of two individual PGPR strains would exhibit better overall biocontrol and plant-growth promotion than the individual PGPR strains. Two separate greenhouse experiments were conducted. In each experiment, two individual PGPR strains and their mixtures were tested for biological control of three different diseases and for plant-growth promotion in the presence of the pathogens. The results demonstrated that the two individual PGPR strains and their mixtures exhibited both biological control of multiple plant diseases and plantgrowth promotion. Overall, the levels of disease suppression and growth promotion were greater with mixtures than with individual PGPR strains.
\end{abstract}

Crop production is heavily dependent on pesticides to manage diseases and pests (Sivasakthi et al. 2014) and on chemical fertilizers to provide sufficient nutrients for optimizing crop yields (Gruhn et al. 2000). However, public concern has been raised regarding how the exclusive reliance on the use of pesticides and chemically synthesized fertilizers can result in development of pathogen resistance to pesticides (Georghiou 2012), environmental pollution (Zhang et al. 2011), contamination of surface and ground waters (Savci 2012), and deleterious nontarget effects on humans, beneficial soil microorganisms, insects, birds, and fish (Muñoz-Leoz et al. 2013). One way to address these concerns is to develop and implement alternative control approaches for crop protection such as biopesticides and biofertilizers containing plant-growth-promoting rhizobacteria (PGPR) (Banerjee et al. 2005; Chandler et al. 2011; Subba Rao 1993). PGPR are a group of beneficial bacteria that influence the growth (Huang et al. 2016), yield (Liu et al. 2016b), and nutrient uptake of plants (Calvo et al. 2016), and that often exhibit biological control of plant disease (Xiang et al. 2017b).

The majority of published reports of plant disease biocontrol evaluate single PGPR strains against a single pathogen (Zhang et al. 2010). Huang et al. (2012) reported that the antibiotic-producing bacterium Bacillus pumilis strain SQR-N43 directly inhibited dampingoff of cucumber, caused by Rhizoctonia solani. B. subtilis strains NH-100 and NH-160 exhibited biocontrol of red rot of sugarcane, caused by Colletotrichum falcatum (Hassan et al. 2010). In another study, Aliye et al. (2008) reported that B. subtilis strains PFMRI, BS-DFS, and PF9 protected against bacterial wet rot of potato, caused by Ralstonia solanacearum. Biological control of mango anthracnose, caused by C. gloeosporioides, was reported using Pseudomonas fluorescens strain FP7 (Vivekananthan et al. 2004).

Despite the positive results reported in the preceding examples, single PGPR strains have not been used on a wide range of plant hosts and have typically often exhibited inconsistent performance in the field for various reasons (Pal and Gardener 2006). First, a single PGPR strain typically does not exhibit biological control against

${ }^{\dagger}$ Corresponding author: J. W. Kloepper; E-mail: kloepjw@ @uburn.edu

Accepted for publication 4 August 2017.

(c) 2018 The American Phytopathological Society multiple pathogens (Backman et al. 1997). Second, a single strain is not likely to be active at a high enough level against multiple pathogens under diverse environmental conditions found in the field (Elmqvist et al. 2003). The formulation of mixtures of PGPR is one strategy to address multiple modes of action and biocontrol of multiple pathogens (Jetiyanon and Kloepper 2002).

Several studies have shown that mixtures of PGPR could enhance biological control activity for multiple plant diseases through induced systemic resistance (Raupach and Kloepper 1998), and for a single plant disease through antagonism (Xiang et al. 2017a). A few studies have been conducted to determine whether mixtures of PGPR strains can enhance biological control activity of multiple plant diseases through antagonism (Domenech et al. 2006). In these studies, the PGPR treatments were applied to the soil to control multiple soilborne diseases.

In addition to exhibiting biological control, some mixtures of PGPR enhance aspects of plant growth, including the germination rate (Jahanian et al. 2012), shoot and root weight (Siddiqui and Shaukat 2002), and yield (Nandakumar et al. 2001). Root architecture plays an important role in plant development, including nutrient uptake (Wang et al. 2011), water absorption capacity (Bresson et al. 2013), and tolerance to abiotic and biotic stress (Sukumar et al. 2013).

In a previous study, we reported that four individual PGPR strains (B. altitudinis AP69 and B. velezensis AP197, AP199, and AP298) demonstrated broad-spectrum biocontrol activity through the mechanism of antagonism in growth chambers against two foliar bacterial pathogens (Xanthomonas axonopodis pv. vesicatoria and $P$. syringae pv. tomato) and one of two soilborne fungal pathogens ( $R$. solani or Pythium ultimum) (Liu et al. 2017). Also, these four strains exhibited four traits reported to be related to plant-growth promotion, including nitrogen fixation, indole-3-acetic acid production, siderophore production, and biofilm formation (Liu et al. 2017). The objective of the current study was to evaluate mixtures of PGPR strains for biological control of multiple plant diseases, promotion of plant growth, and enhancement of root architecture.

\section{Materials and Methods}

PGPR cultures. Five PGPR strains (B. altitudinis strain AP69 and B. velezensis strains AP197, AP199, AP298, and GB03) from the culture collection of Auburn University were used in the study. The bacteria were maintained in tryptic soy broth (TSB) (Difco Laboratories, Detroit), supplemented with $30 \%$ glycerol at $-80^{\circ} \mathrm{C}$. PGPR 
were grown on tryptic soy agar (TSA) at $28^{\circ} \mathrm{C}$ for $48 \mathrm{~h}$. A single colony was incubated in $25 \mathrm{ml}$ of TSB with continuous shaking (150 rpm) at $28^{\circ} \mathrm{C}$ for $48 \mathrm{~h}$. The bacterial culture was centrifuged at 3,500 rpm for $15 \mathrm{~min}$. Pellets were resuspended in sterilized water, and the concentration was adjusted to $10^{6} \mathrm{CFU} / \mathrm{ml}$.

Pathogens and culture conditions. Four plant pathogens from the Phytobacteriology Lab of Auburn University were tested in this study: P. ultimum, $R$. solani, $X$. axonopodis pv. vesicatoria, and Pseudomonas syringae pv. tomato. The pathogenic fungi were maintained on slants of corn meal agar at room temperature for long-term storage and were transferred onto potato dextrose agar plates for experimental use. Millet seed inoculum of Pythium ultimum was prepared as described by Howell (2007). Granules of $P$. ultimum inoculum were ground and stored in a sterile container at room temperature. The pathogenic bacteria were stored under the conditions described above and were prepared to $10^{7} \mathrm{CFU} / \mathrm{ml}$ by the same method for experimental use.

Greenhouse study. Two separate experiments, described as experiment $\mathrm{A}$ and experiment $\mathrm{B}$, were conducted in the greenhouse. In each experiment, six treatments were included: two treatments consisting of single PGPR strains (AP69 and AP199 in experiment A and AP197 and AP298 in experiment B), a treatment consisting of a strain mixture (mixture of AP69 and AP199 in experiment A and mixture of AP197 and AP298 in experiment B), B. velezensis strain GB03 as a positive control, a nonbacterized but pathogenchallenged disease control, and a nontreated healthy control. The specific diseases and hosts tested were bacterial spot of tomato, caused by $X$. axonopodis pv. vesicatoria, and bacterial speck of tomato, caused by $P$. syringae pv. tomato, in experiment A and experiment B; damping-off of cucumber, caused by $P$. ultimum, in experiment $\mathrm{A}$; and damping-off of pepper, caused by $R$. solani, in experiment $\mathrm{B}$. The compatibility of the strains in the mixtures was determined on TSA plates. Bacterial strains were streaked at a $90^{\circ}$ angle from each other. The plates were incubated at $28^{\circ} \mathrm{C}$ for $48 \mathrm{~h}$ and observed for the presence or absence of an inhibition zone. Absence of an inhibition zone indicated compatibility of the tested strains, whereas the presence of inhibition zones indicated incompatibility. Mixtures of PGPR strains were prepared by combining equal proportions of each strain, and each individual strain took half the rate of the amount in the mixture. Each experiment was conducted twice and was arranged in a randomized complete block design with 10 replications per treatment.

In the test of fungal diseases, $5.0 \mathrm{~cm}^{3}$ of millet granules of $P$. ultimum or nine mycelial plugs $(7 \mathrm{~mm}$ ) of $R$. solani from the edge of pregrown cultures were applied to $1,800 \mathrm{~cm}^{3}$ of commercial potting substrate (Sunshine mix; Sun Gro Horticulture, Agawam, MA). Ten seeds of 'Diva' cucumber or 'California Wonder' bell pepper (Park Seed, Hodges, SC) were mixed into the 20-cm-round plastic pot (20 cm in diameter by $14 \mathrm{~cm}$ in height) at $24 \mathrm{~h}$ after pathogen inoculation. PGPR suspension $\left(1 \mathrm{ml}, 10^{6} \mathrm{CFU} / \mathrm{ml}\right)$ was applied to each seed prior to covering with $570 \mathrm{~cm}^{3}$ of potting substrate. Plants were placed in a temperature-controlled greenhouse at the Plant Science Research Center at Auburn University. Ambient air temperature in the greenhouse was maintained at 25 and $21^{\circ} \mathrm{C}$ (day and night, respectively) throughout the year. Incidence of preemergence damping-off and postemergence damping-off was recorded at 7 and 14 days, respectively, after sowing the seed for P. ultimum and at 21 and 28 days for $R$. solani. The disease severity of $P$. ultimum root lesions was rated using a 0 -to- 4 rating scale, where $0=$ healthy white roots at crown with abundant root branching and good overall length, $1=$ short and stubby white roots at crown with restricted overall length, 2 = stubby roots at crown with some browning, $3=$ severely stunted plant with few roots at crown and browning of main root, and $4=$ dead root. The disease severity of $R$. solani root lesions was rated using a 0 -to-5 rating scale, where $0=$ healthy, $1=<10 \%$ dark-brown lesion at crown, $2=10$ to $25 \%$ of the crown girdled with necrotic lesion, $3=26$ to $50 \%$ of the crown girdled with necrotic lesion, $4=51$ to $75 \%$ of the crown girdled with necrotic lesion, and $5=76$ to $100 \%$ of the crown girdled with necrotic lesions.
In the test of bacterial diseases, 'Rutgers Select' tomato seed (Park Seed) were planted in germination trays containing $25-\mathrm{cm}^{3}$ holes and grown for 3 weeks. Then, seedlings were transplanted into a $10-\mathrm{cm}^{2}$ plastic pot filled with $600 \mathrm{~cm}^{3}$ of potting substrate. Two weeks after transplanting, plants were sprayed with PGPR suspensions $\left(10^{6} \mathrm{CFU} / \mathrm{ml}\right)$ for foliar application. PGPR-inoculated plants were placed into a dark dew chamber ( $100 \%$ humidity) for 2 days at $24^{\circ} \mathrm{C}$, then moved to the greenhouse. Three days after spraying with PGPR, plants were challenge inoculated with $X$. axonopodis $\mathrm{pv}$. vesicatoria or $P$. syringae pv. tomato by spraying the whole plant. Pathogeninoculated plants were placed into the same dew chamber for 2 days, then placed in the greenhouse. The disease severity was assessed at 7 days after pathogen challenge for bacterial spot and at 14 days for bacterial speck. In the rating of disease, four compound leaves were chosen from the bottom of each plant, and the disease severities of compound leaf were averaged by the disease severity of leaflets on that compound leaf. The leaflet was rated using a 0 -to-4 rating scale, where $0=$ healthy leaflet; $1=<20,2=20$ to 50 , and $3=51$ to $80 \%$ necrotic area of leaflet; and $4=80$ to $100 \%$ necrotic area of leaflet or fully dead leaflet.

Plants were harvested at the same time and shoot dry weight (oven dry at $90^{\circ} \mathrm{C}$ for $48 \mathrm{~h}$ ) was measured. Plant roots were analyzed for root morphology using the WinRHIZO Arabidopsis software v2009c 32-bit (Regent Instruments, Quebec, QC, Canada) system connected to an Epson XL 10000 professional scanner. Each root system was evenly spread apart in a water layer on a transparent tray and imaged at a resolution of 400 dpi (Bauhus and Messier 1999; Costa et al. 2000). The following root characteristics were determined: total root length (in centimeters), root surface area (in square centimeters), and total root length of fine roots with diameter range of 0 to $0.5 \mathrm{~mm}$. Once the root morphological characteristics were determined, root samples were oven dried $\left(90^{\circ} \mathrm{C}\right)$ to determine root dry weight.

Statistical analysis. All data were analyzed by analysis of variance, and the treatment means were separated by using Fisher's protected least significant difference test at $P=0.05$ using SAS software (version 9.4; SAS Institute, Cary, NC). Fixed effects were treatments and the random effects included replication and test repeat. Disease severity data were $\log$-transformed $\left(\log _{(\mathrm{x}+1)}\right)$ before data analysis. The original mean values ( \pm standard error) are presented in the tables with $P$ values to determine statistical differences.

\section{Results}

Compatibility of mixed strains. Mixed PGPR strains were tested for their compatibility in vitro. None of the bacteria were inhibited by other bacteria; thus, the absence of an inhibition zone suggested that these mixed strains were compatible with each other.

Biological control activity to multiple plant diseases. In experiment A, all of the tested treatments significantly decreased the disease severity of $X$. axonopodis pv. vesicatoria $(P<0.001)$ but the mixture exhibited a higher level of disease reduction compared with either AP197 and AP298 alone (Table 1). Treatments AP197 and the mixture (AP197 + AP298) significantly decreased the disease severity of $P$. syringae pv. tomato $(P<0.001)$. AP298 significantly reduced preemergence damping-off cause by $R$. solani $(P<0.001)$, and treatments AP197 and the mixture (AP197 + AP298) significantly reduced both postemergence damping-off $(P=0.0403)$ and the disease severity $(P=0.0019)$. In experiment $\mathrm{A}$, means of disease reduction were $42.0 \%$ for the mixture (AP197 + 298) and 39.7, 18.5, and $26.5 \%$ for AP197, AP298, and the positive control, respectively.

In experiment B, treatments AP69, AP199, the mixture (AP69 + AP199), and the positive control (GB03) significantly reduced disease severity of $X$. axonopodis pv. vesicatoria, $P$. syringae $\mathrm{pv}$. tomato, and $P$. ultimum $(P<0.001)$ compared with the disease control (Table 2$)$. In the test of $P$. ultimum, treatments AP199 and the mixture (AP69+ AP199) significantly reduced preemergence damping-off $(P<0.001)$, and AP69 and AP199 significantly reduced postemergence dampingoff $(P<0.001)$. In experiment, $\mathrm{B}$, means of disease reduction were $44.0 \%$ for the mixture (AP69 + 199) and 44.1, 41.9, and 40.9\% for AP69, AP199, and the positive control, respectively. 
Plant-growth promotion in the presence of pathogens. Two separate experiments were conducted in the greenhouse. Each experiment separately included three different diseases. In each disease test, five growth parameters, including shoot dry weight, root dry weight, total root length, root surface area, and total root length of fine roots with diameter range of 0 to $0.5 \mathrm{~mm}$, were collected (Table 3). Hence, a total of 15 growth parameters were collected in each experiment.

In the test of $X$. axonopodis pv. vesicatoria in experiment A, the mixture significantly increased three growth parameters compared with the disease control, including root dry weight $(P=0.0010)$, root surface area $(P=0.0002)$, and total length of fine roots $(P=0.0023)$. In addition, root length $(P=0.0019)$ and total length of fine roots $(P=0.0023)$ of the mixture were statistically equivalent to the healthy control. In the test of $P$. syringae pv. tomato, the mixture significantly increased all five tested growth parameters $(P<0.001)$. Root length $(P<0.001)$ and root surface area $(P<0.001)$ of the mixture were significantly higher than the individual PGPR treatments AP197 and AP298 alone and were statistically equivalent to the healthy control. In the test of $R$. solani, treatments AP197 and the mixture (AP197+ AP298) significantly enhanced five tested growth parameters $(P<$ $0.001)$. In summary, the mixture significantly increased 13 of the 15 total growth parameters, while individual strains AP 197, AP298, and the positive control significantly increased 8,6 , and 4 growth parameters, respectively.

In the test of $X$. axonopodis pv. vesicatoria experiment $\mathrm{B}$, the mixture (AP69 + AP199), the individual strains AP69 and AP199, and the positive control (GB03) significantly enhanced total root length $(P=0.0002)$ compared with the disease control. In the presence of $P$. syringae pv. tomato, the mixture significantly increased three growth parameters, including root dry weight, root length, and root surface area $(P<0.001)$. The individual strains and positive control did not enhance root dry weight but did promote root length and root surface area. In the test of $P$. ultimum, individual strain AP199 increased all five collected growth parameters $(P<0.001)$, whereas the mixture significantly increased four growth parameters. In summary, individual PGPR strain AP199 and the mixtures significantly increased 8 of the 15 total growth parameters, while individual strains AP 69 and the positive control significantly enhanced 3 growth parameters.

\section{Discussion}

Overall, in two separate experiments consisting of three different pathosystems and tests repeated twice, the PGPR strain mixture exhibited higher levels of disease suppression through antagonistic activity compared with individual PGPR strains (Tables 1 and 2). Also, some of our single PGPR strains exhibited a higher level of disease suppression compared with the positive control (GB03). A similar finding was reported in a biocontrol study of cabbage black rot (Liu et al. 2016a). The combination of different mechanisms for pathogen suppression of each individual PGPR strain may account for the effectiveness of some mixtures of PGPR. For example, in a study of biological control of rice sheath blight, Sung and Chung (1997) found that a combination of four PGPR strains, in which two strains produced chitinase and the other two produced antibiotics, resulted in a synergistic effect on disease suppression. In our previous study (Liu et al. 2017), we found that some common secondary metabolites such as bacillibactin, bacilysin, and microcin were detected in stains AP197 and AP298, and that each strain also produced a specific secondary metabolite: haloduracin $\alpha$ by strain AP197 and bacillomycin by strain AP298. Strain GB03 has frequently been used as a representative commercialized strain for biological control against a broad spectrum of plant pathogens, including Pythium spp. (Corrêa et al. 2010), Rhizoctonia spp. (Brewer and Larkin 2005), Fusarium spp. (Brannen and Kenney 1997), Pseudomonas spp. (Raupach and Kloepper 1998), and Xanthomonas spp. (Chandler et al. 2011). In the current study, the comparison

Table 1. Experiment A: Effect of plant-growth-promoting rhizobacteria on disease protection after pathogen challenge under greenhouse conditions ${ }^{\mathrm{y}}$

\begin{tabular}{|c|c|c|c|c|c|}
\hline \multirow[b]{3}{*}{ Treatment } & \multicolumn{5}{|c|}{ Pathogens $^{\mathrm{z}}$} \\
\hline & \multirow{2}{*}{$\frac{\text { Xanthomonas }}{\mathrm{DS}}$} & \multirow{2}{*}{$\frac{\text { Pseudomonas }}{\text { DS }}$} & \multicolumn{3}{|c|}{ Rhizoctonia solani on pepper } \\
\hline & & & Pre & Post & DS \\
\hline Disease & $1.88 \pm 0.09 \mathrm{a}$ & $1.32 \pm 0.16 \mathrm{a}$ & $55.0 \pm 5.2 \mathrm{a}$ & $26.1 \pm 8.0 \mathrm{a}$ & $0.71 \pm 0.32 \mathrm{a}$ \\
\hline AP197 & $1.44 \pm 0.07 b$ & $0.80 \pm 0.14 b$ & $51.3 \pm 2.0 \mathrm{ab}$ & $5.8 \pm 6.6 b$ & $0.31 \pm 0.10 \mathrm{bc}$ \\
\hline AP298 & $1.53 \pm 0.09 b$ & $1.13 \pm 0.18 \mathrm{ab}$ & $46.0 \pm 7.2 \mathrm{~b}$ & $13.9 \pm 5.1 \mathrm{ab}$ & $0.55 \pm 0.14 \mathrm{ab}$ \\
\hline AP197 + AP298 & $1.23 \pm 0.08 \mathrm{c}$ & $0.80 \pm 0.15 b$ & $51.0 \pm 3.5 \mathrm{ab}$ & $7.5 \pm 4.9 \mathrm{~b}$ & $0.34 \pm 0.13 b$ \\
\hline GB03 & $1.50 \pm 0.07 b$ & $1.17 \pm 0.26 \mathrm{ab}$ & $53.3 \pm 3.9 \mathrm{a}$ & $13.6 \pm 5.0 \mathrm{ab}$ & $0.37 \pm 0.16 b$ \\
\hline Healthy & $0.00 \pm 0.00 \mathrm{~d}$ & $0.00 \pm 0.00 \mathrm{c}$ & $11.0 \pm 2.3 \mathrm{c}$ & $0.0 \pm 0.0 \mathrm{~b}$ & $0.00 \pm 0.00 \mathrm{c}$ \\
\hline$P$ value & $<0.0001$ & $<0.0001$ & $<0.0001$ & 0.0403 & 0.0019 \\
\hline
\end{tabular}

y Values (mean \pm standard error) in the same column followed by the same letter are not significantly different at $P=0.05$ according to Fisher's protected least significant difference.

${ }^{\mathrm{z}}$ Abbreviations: Xanthomonas = Xanthomonas axonopodis pv. vesicatoria on tomato, Pseudomonas = Pseudomonas syringae pv. tomato on tomato, DS = disease severity, Pre $=$ Preemergence damping-off, and Post $=$ Postemergence damping-off.

Table 2. Experiment B: Effect of plant-growth-promoting rhizobacteria on disease protection after pathogen challenge under greenhouse conditions ${ }^{\mathrm{y}}$

\begin{tabular}{|c|c|c|c|c|c|}
\hline \multirow[b]{3}{*}{ Treatment } & \multicolumn{5}{|c|}{ Pathogens $^{\mathrm{z}}$} \\
\hline & \multirow{2}{*}{$\frac{\text { Xanthomonas }}{\text { DS }}$} & \multirow{2}{*}{$\frac{\text { Pseudomonas }}{\text { DS }}$} & \multicolumn{3}{|c|}{ Pythium ultimum on cucumber } \\
\hline & & & Pre & Post & DS \\
\hline Disease & $2.48 \pm 0.10 \mathrm{a}$ & $1.53 \pm 0.07 \mathrm{a}$ & $85.0 \pm 2.4 \mathrm{ab}$ & $38.2 \pm 10.2 \mathrm{a}$ & $2.00 \pm 0.22 \mathrm{a}$ \\
\hline AP69 & $1.85 \pm 0.12 b$ & $0.60 \pm 0.10 \mathrm{c}$ & $79.0 \pm 4.1 \mathrm{bc}$ & $22.4 \pm 6.5 \mathrm{~b}$ & $1.08 \pm 0.16 b$ \\
\hline AP199 & $1.90 \pm 0.12 b$ & $0.80 \pm 0.11 b c$ & $72.0 \pm 3.5 \mathrm{c}$ & $22.7 \pm 5.9 \mathrm{~b}$ & $0.91 \pm 0.21 \mathrm{bc}$ \\
\hline $\mathrm{AP} 69+\mathrm{AP} 199$ & $1.87 \pm 0.12 b$ & $0.62 \pm 0.08 \mathrm{c}$ & $77.0 \pm 4.2 \mathrm{c}$ & $28.6 \pm 7.3 \mathrm{ab}$ & $1.04 \pm 0.12 b$ \\
\hline GB03 & $1.93 \pm 0.12 b$ & $0.88 \pm 0.08 \mathrm{~b}$ & $86.5 \pm 3.0 \mathrm{a}$ & $33.6 \pm 9.3 \mathrm{ab}$ & $0.84 \pm 0.19 b$ \\
\hline Healthy & $0.00 \pm 0.00 \mathrm{c}$ & $0.00 \pm 0.00 \mathrm{~d}$ & $7.5 \pm 1.8 \mathrm{~d}$ & $0.0 \pm 0.0 \mathrm{c}$ & $0.50 \pm 0.11 \mathrm{c}$ \\
\hline$P$ value & $<0.0001$ & $<0.0001$ & $<0.0001$ & $<0.0001$ & $<0.0001$ \\
\hline
\end{tabular}

${ }^{\mathrm{y}}$ Values (mean \pm standard error) in the same column followed by the same letter are not significantly different at $P=0.05$ according to Fisher's protected least significant difference.

${ }^{\mathrm{z}}$ Abbreviations: Xanthomonas $=$ Xanthomonas axonopodis pv. vesicatoria on tomato, Pseudomonas $=$ Pseudomonas syringae pv. tomato on tomato, DS $=$ disease severity, Pre $=$ Preemergence damping-off, and Post $=$ Postemergence damping-off. 
with GB03 indicated that some PGPR strains were as effective or better than this reference strain.

In addition to eliciting defense to multiple plant diseases, PGPR treatments also promoted growth of different hosts in the presence of pathogens, with a general trend for the best results occurring with mixtures (Table 3). These results are similar to those of Goudjal et al. (2014), in which two isolates of actinomycetes provided biological control of $R$. solani damping-off and promoted shoot root weights of tomato. In addition, our results show that application of PGPR treatments enhanced some parameters of root morphology, an effect that has been demonstrated with PGPR strains in several crops, including tomato (Gamalero et al. 2002), cucumber (Gamalero et al. 2008), and chickpea (Shahzad et al. 2010). Root morphological parameters play an important role in plant development because nutrient uptake is more dependent on root length and root surface area than on total root biomass (Boot 1989). Hence, enhancement of nutrient uptake sometimes results from PGPR treatments, as found by Gamalero et al. (2004), who reported an increase in $\mathrm{P}$ acquisition that was related to plant-growth promotion by PGPR.

Table 3. Effect of plant-growth-promoting rhizobacteria on plant-growth parameters and root morphology parameters after pathogen challenge under greenhouse conditions $^{\mathrm{x}}$

\begin{tabular}{|c|c|c|c|c|c|}
\hline$\overline{\text { Treatment }^{y}}$ & Shoot dry weight (g) & Root dry weight (g) & Root length $(\mathrm{cm})$ & Root surface area $\left(\mathrm{cm}^{2}\right)$ & Fine root length $(\mathrm{mm})^{\mathrm{z}}$ \\
\hline \multicolumn{6}{|l|}{ Experiment A } \\
\hline \multicolumn{6}{|l|}{ Xanthomonas } \\
\hline Disease & $1.38 \pm 0.15 \mathrm{ab}$ & $0.166 \pm 0.024 \mathrm{c}$ & $1,054 \pm 105 b$ & $135 \pm 16 \mathrm{c}$ & $868 \pm 81 c$ \\
\hline AP197 & $1.28 \pm 0.13 b$ & $0.191 \pm 0.022 b c$ & $1,116 \pm 95 b$ & $144 \pm 13 b c$ & $917 \pm 76 \mathrm{bc}$ \\
\hline AP298 & $1.35 \pm 0.16 b$ & $0.188 \pm 0.024 b c$ & $1,080 \pm 109 b$ & $138 \pm 14 \mathrm{bc}$ & $899 \pm 90 \mathrm{c}$ \\
\hline AP197 + AP298 & $1.41 \pm 0.14 \mathrm{ab}$ & $0.203 \pm 0.021 \mathrm{~b}$ & $1,200 \pm 106 a b$ & $157 \pm 12 b$ & $1,026 \pm 80 \mathrm{ab}$ \\
\hline GB03 & $1.36 \pm 0.14 \mathrm{ab}$ & $0.177 \pm 0.020 b c$ & $1,159 \pm 104 b$ & $148 \pm 15 b c$ & $958 \pm 82 \mathrm{abc}$ \\
\hline Healthy & $1.61 \pm 0.19 \mathrm{a}$ & $0.241 \pm 0.028 \mathrm{a}$ & $1,323 \pm 100 \mathrm{a}$ & $176 \pm 15 \mathrm{a}$ & $1,075 \pm 79 a$ \\
\hline$P$ value & 0.0448 & 0.0010 & 0.0019 & 0.0002 & 0.0023 \\
\hline \multicolumn{6}{|l|}{ Pseudomonas } \\
\hline Disease & $2.71 \pm 0.06 \mathrm{~d}$ & $0.42 \pm 0.01 \mathrm{~b}$ & $2,086 \pm 63 \mathrm{c}$ & $285 \pm 6 \mathrm{~d}$ & $1,681 \pm 60 \mathrm{c}$ \\
\hline AP197 & $2.97 \pm 0.03 \mathrm{ab}$ & $0.44 \pm 0.01 \mathrm{ab}$ & $2,216 \pm 76 b$ & $312 \pm 11 b$ & $1,708 \pm 60 \mathrm{c}$ \\
\hline AP298 & $2.91 \pm 0.13 b c$ & $0.45 \pm 0.02 \mathrm{ab}$ & $2,017 \pm 47 \mathrm{c}$ & $300 \pm 7 c$ & $1,555 \pm 40 \mathrm{~d}$ \\
\hline AP197 + AP298 & $3.05 \pm 0.08 \mathrm{a}$ & $0.48 \pm 0.02 \mathrm{a}$ & $2,455 \pm 28 \mathrm{a}$ & $322 \pm 6 a$ & $1,870 \pm 57 \mathrm{~b}$ \\
\hline GB03 & $2.84 \pm 0.09 \mathrm{~cd}$ & $0.42 \pm 0.01 \mathrm{~b}$ & $2,065 \pm 55 \mathrm{c}$ & $291 \pm 4 \mathrm{~cd}$ & $1,583 \pm 50 \mathrm{~d}$ \\
\hline Healthy & $2.81 \pm 0.09 \mathrm{~cd}$ & $0.44 \pm 0.02 \mathrm{ab}$ & $2,445 \pm 75 \mathrm{a}$ & $322 \pm 11 \mathrm{a}$ & $1,916 \pm 60 \mathrm{a}$ \\
\hline$P$ value & $<0.0001$ & $<0.0001$ & $<0.0001$ & $<0.0001$ & $<0.0001$ \\
\hline \multicolumn{6}{|l|}{ Rhizoctonia } \\
\hline Disease & $0.176 \pm 0.029 \mathrm{~d}$ & $0.0151 \pm 0.0027 \mathrm{c}$ & $221 \pm 35 \mathrm{e}$ & $25 \pm 4 \mathrm{e}$ & $184 \pm 31 \mathrm{e}$ \\
\hline AP197 & $0.250 \pm 0.027 b c$ & $0.0261 \pm 0.0035 \mathrm{~b}$ & $426 \pm 27 b$ & $45 \pm 3 b$ & $373 \pm 26 b$ \\
\hline AP298 & $0.270 \pm 0.040 \mathrm{~b}$ & $0.0239 \pm 0.0031 b c$ & $362 \pm 47 c$ & $39 \pm 5 c$ & $319 \pm 42 c$ \\
\hline AP197 + AP298 & $0.262 \pm 0.017 \mathrm{~b}$ & $0.0259 \pm 0.0024 \mathrm{~b}$ & $375 \pm 31 \mathrm{c}$ & $40 \pm 4 c$ & $306 \pm 31 \mathrm{c}$ \\
\hline GB03 & $0.231 \pm 0.029 \mathrm{c}$ & $0.0233 \pm 0.0039 b c$ & $328 \pm 28 \mathrm{~d}$ & $32 \pm 2 d$ & $266 \pm 27 \mathrm{~d}$ \\
\hline Healthy & $0.515 \pm 0.029 \mathrm{a}$ & $0.0428 \pm 0.0041 \mathrm{a}$ & $625 \pm 25 a$ & $67 \pm 3 a$ & $545 \pm 23 a$ \\
\hline$P$ value & $<0.0001$ & $<0.0001$ & $<0.0001$ & $<0.0001$ & $<0.0001$ \\
\hline \multicolumn{6}{|l|}{ Experiment B } \\
\hline \multicolumn{6}{|l|}{ Xanthomonas } \\
\hline Disease & $0.481 \pm 0.069 \mathrm{a}$ & $0.0465 \pm 0.0066 b$ & $286 \pm 19 \mathrm{e}$ & $33 \pm 2 b$ & $348 \pm 41 \mathrm{a}$ \\
\hline AP69 & $0.432 \pm 0.068 \mathrm{a}$ & $0.0503 \pm 0.0062 b$ & $312 \pm 19 b c$ & $34 \pm 2 b$ & $334 \pm 40 a$ \\
\hline AP199 & $0.571 \pm 0.068 \mathrm{a}$ & $0.0585 \pm 0.0064 \mathrm{ab}$ & $338 \pm 20 b$ & $37 \pm 2 b$ & $439 \pm 48 a$ \\
\hline AP69 + AP199 & $0.501 \pm 0.068 \mathrm{a}$ & $0.0525 \pm 0.0066 \mathrm{~b}$ & $299 \pm 20 \mathrm{~d}$ & $35 \pm 2 b$ & $336 \pm 48 a$ \\
\hline GB03 & $0.539 \pm 0.066 \mathrm{a}$ & $0.0553 \pm 0.0066 \mathrm{ab}$ & $319 \pm 20 \mathrm{~cd}$ & $37 \pm 2 b$ & $372 \pm 46 a$ \\
\hline Healthy & $0.573 \pm 0.063 \mathrm{a}$ & $0.0787 \pm 0.0060 \mathrm{a}$ & $458 \pm 19 \mathrm{a}$ & $55 \pm 2 \mathrm{a}$ & $394 \pm 45 \mathrm{a}$ \\
\hline$P$ value & 0.1642 & 0.0172 & 0.0002 & $<0.0001$ & 0.3079 \\
\hline \multicolumn{6}{|l|}{ Pseudomonas } \\
\hline Disease & $2.59 \pm 0.11 \mathrm{a}$ & $0.339 \pm 0.014 b$ & $1,748 \pm 55 \mathrm{c}$ & $236 \pm 7 b$ & $1,364 \pm 44 \mathrm{a}$ \\
\hline AP69 & $2.73 \pm 0.09 \mathrm{a}$ & $0.371 \pm 0.016 \mathrm{ab}$ & $1,953 \pm 57 \mathrm{ab}$ & $264 \pm 6 a$ & $1,576 \pm 80 \mathrm{a}$ \\
\hline AP199 & $2.71 \pm 0.12 \mathrm{a}$ & $0.386 \pm 0.014 \mathrm{ab}$ & $2,023 \pm 60 \mathrm{ab}$ & $268 \pm 7 a$ & $1,613 \pm 76 a$ \\
\hline AP69 + AP199 & $2.77 \pm 0.12 \mathrm{a}$ & $0.409 \pm 0.016 \mathrm{a}$ & $2,071 \pm 52 \mathrm{a}$ & $268 \pm 3 a$ & $1,607 \pm 59 \mathrm{a}$ \\
\hline GB03 & $2.67 \pm 0.12 \mathrm{a}$ & $0.386 \pm 0.020 \mathrm{ab}$ & $1,909 \pm 37 b$ & $258 \pm 4 \mathrm{a}$ & $1,500 \pm 54 \mathrm{a}$ \\
\hline Healthy & $2.56 \pm 0.15 \mathrm{a}$ & $0.372 \pm 0.022 \mathrm{ab}$ & $1,973 \pm 59 \mathrm{ab}$ & $256 \pm 9 a$ & $1,559 \pm 45 \mathrm{a}$ \\
\hline$P$ value & 0.7141 & $<0.0001$ & 0.0013 & 0.0125 & 0.0517 \\
\hline \multicolumn{6}{|l|}{ Pythium } \\
\hline Disease & $0.112 \pm 0.035 \mathrm{c}$ & $0.0065 \pm 0.0018 \mathrm{c}$ & $69 \pm 20 d$ & $8 \pm 2 \mathrm{~d}$ & $60 \pm 18 \mathrm{~d}$ \\
\hline AP69 & $0.136 \pm 0.028 \mathrm{c}$ & $0.0111 \pm 0.0020 b c$ & $129 \pm 29 \mathrm{~cd}$ & $15 \pm 3 \mathrm{~cd}$ & $111 \pm 25 \mathrm{~cd}$ \\
\hline AP199 & $0.276 \pm 0.059 \mathrm{~b}$ & $0.0194 \pm 0.0033 \mathrm{~b}$ & $225 \pm 38 \mathrm{bc}$ & $26 \pm 4 \mathrm{bc}$ & $193 \pm 33 \mathrm{bc}$ \\
\hline AP69 + AP199 & $0.245 \pm 0.067 \mathrm{bc}$ & $0.0194 \pm 0.0047 \mathrm{~b}$ & $286 \pm 83 b$ & $31 \pm 9 b$ & $246 \pm 71 b$ \\
\hline GB03 & $0.140 \pm 0.036 b c$ & $0.0085 \pm 0.0019 c$ & $100 \pm 25 \mathrm{~cd}$ & $11 \pm 3 \mathrm{~d}$ & $86 \pm 22 \mathrm{~cd}$ \\
\hline Healthy & $1.450 \pm 0.168 \mathrm{a}$ & $0.0878 \pm 0.0093 \mathrm{a}$ & $696 \pm 123 \mathrm{a}$ & $75 \pm 14 \mathrm{a}$ & $591 \pm 103 \mathrm{a}$ \\
\hline$P$ value & $<0.0001$ & $<0.0001$ & $<0.0001$ & $<0.0001$ & $<0.0001$ \\
\hline
\end{tabular}

x Values (mean \pm standard error) in the same column followed by the same letter are not significantly different at $P=0.05$ according to Fisher's protected least significant difference.

${ }^{y}$ Abbreviations: Xanthomonas $=$ Xanthomonas axonopodis pv. vesicatoria on tomato, Pseudomonas $=$ Pseudomonas syringae pv. tomato on tomato, Rhizoctonia $=$ Rhizoctonia solani on pepper, and Pythium $=$ Pythium ultimum on cucumber.

$\mathrm{z}$ Total length of fine roots with a diameter range of 0 to $0.5 \mathrm{~mm}$. 
Based on the benefits discussed above, PGPR treatments should ideally exhibit both biocontrol and growth promotion activity. In experiment $\mathrm{A}$, the mixture was the best treatment because it showed the highest level of disease reduction and growth promotion compared with other treatments. In experiment B, although AP69 exhibited $0.01 \%$ higher disease reduction compared with the mixture, this individual strain did not show the best growth promotion, whereas the mixture in experiment $\mathrm{B}$ was the best treatment when considering both biocontrol and growth promotion. These results are in agreement with the study by (Latha et al. 2009), in which a mixture of Pseudomonas fluorescens strain Py15 and B. subtilis strain Bs16 caused $45.3 \%$ Alternaria solani disease reduction, thereby demonstrating that the disease reduction of the mixture was lower than each individual strain (Py15 at 59.8\% and Bs16 at 49.1). However, the fruit yield increase of this mixture (41.6\%) was higher than each individual strain (Py15 at 35.6\% and Bs16 at 36.6\%).

Interestingly, in our study, an increase in root weight and root morphology was seen with foliar application of PGPR. This enhancement of root weight may be caused by the PGPR-associated enhancement of photosynthesis, which provides the basic energy to the root. Conversely, enhanced roots can absorb more water and nutrition from the soil to support shoot growth. In a study of foliar application of PGPR, (Mathiyazhagan et al. 2004) found that B. subtilis strain BSCBE4 reduced disease incidence of stem blight of Phyllanthus amarus (caused by Corynespora cassiicola) and increased root length. The authors suggested that the observed increase in plant biomass may be due to the production of plant-growth promoters and antibiotics. In agreement with this suggestion, the strains tested in our study previously exhibited multiple traits related to plant-growth promotion and broad-spectrum biocontrol activity in vitro (Liu et al. 2017).

In summary, the results reported here show that the tested individual PGPR strains and their mixtures exhibited both biological control of multiple plant diseases and plant-growth promotion. The magnitude of these results was better with mixtures than with individual PGPR strains. Future studies should evaluate whether PGPR mixtures provide similar enhanced biological control and growth promotion in field tests.

\section{Acknowledgments}

We thank L. Carter for technical assistance and the United States Department of Agriculture National Institute for Food and Agriculture Hatch program for support.

\section{Literature Cited}

Aliye, N., Fininsa, C., and Hiskias, Y. 2008. Evaluation of rhizosphere bacterial antagonists for their potential to bioprotect potato (Solanum tuberosum) against bacterial wilt (Ralstonia solanacearum). Biol. Control 47:282-288.

Backman, P., Wilson, M., and Murphy, J. 1997. Bacteria for biological control of plant diseases. Pages 95-109 in: Environmentally Safe Approaches to Crop Disease Control. J. E. Rechcigl and N. A. Rechcigl, eds. Lewis Publishers, Boca Raton, FL.

Banerjee, M. R., Yesmin, L., Vessey, J. K., and Rai, M. 2005. Plant-growthpromoting rhizobacteria as biofertilizers and biopesticides. Pages 137-181 in: Handbook of Microbial Biofertilizers. M. K. Rai, ed. Food Products Press, New York.

Bauhus, J., and Messier, C. 1999. Evaluation of fine root length and diameter measurements obtained using RHIZO image analysis. Agron. J. 91:142-147.

Boot, R. G. 1989. The significance of size and morphology of root systems for nutrient acquisition and competition. Pages 299-311 in: Causes and Consequences of Variation in Growth Rate and Productivity of Higher Plants. H. Lambers, M. L. Cambridge, H. Konings, and T. L. Pons, eds. SPB Academic Publishing, Hague, The Netherlands.

Brannen, P. M., and Kenney, D. S. 1997. Kodiak®—A successful biologicalcontrol product for suppression of soil-borne plant pathogens of cotton. J. Ind. Microbiol. Biotechnol. 19:169-171.

Bresson, J., Varoquaux, F., Bontpart, T., Touraine, B., and Vile, D. 2013. The PGPR strain Phyllobacterium brassicacearum STM196 induces a reproductive delay and physiological changes that result in improved drought tolerance in Arabidopsis. New Phytol. 200:558-569.

Brewer, M. T., and Larkin, R. P. 2005. Efficacy of several potential biocontrol organisms against Rhizoctonia solani on potato. Crop Prot. 24:939-950.

Calvo, P., Watts, D. B., Kloepper, J. W., and Torbert, H. A. 2016. Effect of microbial-based inoculants on nutrient concentrations and early root morphology of corn (Zea mays). J. Plant Nutr. Soil Sci. 180:56-70.
Chandler, D., Bailey, A. S., Tatchell, G. M., Davidson, G., Greaves, J., and Grant, W. P. 2011. The development, regulation and use of biopesticides for integrated pest management. Philos. Trans. R. Soc. B 366:1987-1998.

Corrêa, É. B., Bettiol, W., and Sutton, J. C. 2010. Biocontrol of root rot (Pythium aphanidermatum) and growth promotion with Pseudomonas chlororaphis 63 28 and Bacillus subtilis GB03 in hydroponic lettuce. Summa Phytopathol. 36: 275-281.

Costa, C., Dwyer, L. M., Hamilton, R. I., Hamel, C., Nantais, L., and Smith, D. L. 2000. A sampling method for measurement of large root systems with scannerbased image analysis. Agron. J. 92:621-627.

Domenech, J., Reddy, M., Kloepper, J., Ramos, B., and Gutierrez-Manero, J. 2006. Combined application of the biological product LS213 with Bacillus, Pseudomonas or Chryseobacterium for growth promotion and biological control of soil-borne diseases in pepper and tomato. BioControl 51:245-258.

Elmqvist, T., Folke, C., Nyström, M., Peterson, G., Bengtsson, J., Walker, B., and Norberg, J. 2003. Response diversity, ecosystem change, and resilience. Front Ecol. Environ 1:488-494.

Gamalero, E., Berta, G., Massa, N., Glick, B. R., and Lingua, G. 2008. Synergistic interactions between the ACC deaminase-producing bacterium Pseudomonas putida UW4 and the AM fungus Gigaspora rosea positively affect cucumber plant growth. FEMS Microbiol. Ecol. 64:459-467.

Gamalero, E., Martinotti, M. G., Trotta, A., Lemanceau, P., and Berta, G. 2002 Morphogenetic modifications induced by Pseudomonas fluorescens A6RI and Glomus mosseae BEG12 in the root system of tomato differ according to plant growth conditions. New Phytol. 155:293-300.

Gamalero, E., Trotta, A., Massa, N., Copetta, A., Martinotti, M., and Berta, G. 2004. Impact of two fluorescent pseudomonads and an arbuscular mycorrhizal fungus on tomato plant growth, root architecture and $\mathrm{P}$ acquisition. Mycorrhiza 14:185-192.

Georghiou, G. P. 2012. Pest Resistance to Pesticides. Springer Science \& Business Media, Boston, MA.

Goudjal, Y., Toumatia, O., Yekkour, A., Sabaou, N., Mathieu, F., and Zitouni, A 2014. Biocontrol of Rhizoctonia solani damping-off and promotion of tomato plant growth by endophytic actinomycetes isolated from native plants of Algerian Sahara. Microbiol. Res. 169:59-65.

Gruhn, P., Goletti, F., and Yudelman, M. 2000. Integrated Nutrient Management Soil Fertility, and Sustainable Agriculture: Current Issues and Future Challenges. International Food Policy Research Institute, Washington, DC.

Hassan, M. N., Afghan, S., and Hafeez, F. Y. 2010. Suppression of red rot caused by Colletotrichum falcatum on sugarcane plants using plant growth-promoting rhizobacteria. BioControl 55:531-542.

Howell, C. R. 2007. Effect of seed quality and combination fungicide-Trichoderma spp. seed treatments on pre- and postemergence damping-off in cotton. Phytopathology 97:66-71.

Huang, P., de-Bashan, L., Crocker, T., Kloepper, J. W., and Bashan, Y. 2016 Evidence that fresh weight measurement is imprecise for reporting the effect of plant growth-promoting (rhizo) bacteria on growth promotion of crop plants. Biol. Fertil. Soils 53:199-208.

Huang, X., Zhang, N., Yong, X., Yang, X., and Shen, Q. 2012. Biocontrol of Rhizoctonia solani damping-off disease in cucumber with Bacillus pumilus SQR-N43. Microbiol. Res. 167:135-143.

Jahanian, A., Chaichi, M. R., Rezaei, K., Rezayazdi, K., and Khavazi, K. 2012. The effect of plant growth promoting rhizobacteria (PGPR) on germination and primary growth of artichoke (Cynara scolymus). Int. J. Agric. Crop Sci 4:923-929.

Jetiyanon, K., and Kloepper, J. W. 2002. Mixtures of plant growth-promoting rhizobacteria for induction of systemic resistance against multiple plant diseases. Biol. Control 24:285-291.

Latha, P., Anand, T., Rappathi, N., Prakasam, V., and Samiyappan, R. 2009. Antimicrobial activity of plant extracts and induction of systemic resistance in tomato plants by mixtures of PGPR strains and Zimmu leaf extract against Alternaria solani. Biol. Control 50:85-93.

Liu, K., Garrett, C., Fadamiro, H., and Kloepper, J. W. 2016a. Antagonism of black rot in cabbage by mixtures of plant growth-promoting rhizobacteria (PGPR) BioControl 61:605-613

Liu, K., Garrett, C., Fadamiro, H., and Kloepper, J. W. 2016b. Induction of systemic resistance in Chinese cabbage against black rot by plant growthpromoting rhizobacteria. Biol. Control 99:8-13.

Liu, K., Newman, M., McInroy, J. A., Hu, C.-H., and Kloepper, J. W. 2017 Selection and assessment of plant growth-promoting rhizobacteria for biological control of multiple plant diseases. Phytopathology 107:928936.

Mathiyazhagan, S., Kavitha, K., Nakkeeran, S., Chandrasekar, G., Manian, K., Renukadevi, P., Krishnamoorthy, A., and Fernando, W. 2004. PGPR mediated management of stem blight of Phyllanthus amarus (Schum and Thonn) caused by Corynespora cassiicola (Berk and Curt) Wei. Arch. Phytopathol. Plant Prot. 37:183-199.

Muñoz-Leoz, B., Garbisu, C., Charcosset, J.-Y., Sánchez-Pérez, J. M., Antigüedad, I., and Ruiz-Romera, E. 2013. Non-target effects of three formulated pesticides on microbially-mediated processes in a clay-loam soil. Sci. Total Environ. 449: 345-354.

Nandakumar, R., Babu, S., Viswanathan, R., Sheela, J., Raguchander, T., and Samiyappan, R. 2001. A new bio-formulation containing plant growth promoting 
rhizobacterial mixture for the management of sheath blight and enhanced grain yield in rice. BioControl 46:493-510.

Pal, K. K., and Gardener, B. M. 2006. Biological control of plant pathogens. Plant Health Instruct. 2:1117-1142.

Raupach, G. S., and Kloepper, J. W. 1998. Mixtures of plant growth-promoting rhizobacteria enhance biological control of multiple cucumber pathogens. Phytopathology 88:1158-1164.

Savci, S. 2012. An agricultural pollutant: Chemical fertilizer. Int. J. Environ. Sci. Dev. 3:73-80.

Shahzad, S. M., Khalid, A., Arshad, M., Tahir, J., and Mahmood, T. 2010. Improving nodulation, growth and yield of Cicer arietinum L. through bacterial ACC-deaminase induced changes in root architecture. Eur. J. Soil Biol. 46: 342-347.

Siddiqui, I., and Shaukat, S. 2002. Mixtures of plant disease suppressive bacteria enhance biological control of multiple tomato pathogens. Biol. Fertil. Soils 36: 260-268.

Sivasakthi, S., Usharani, G., and Saranraj, P. 2014. Biocontrol potentiality of plant growth promoting bacteria (PGPR)—Pseudomonas fluorescens and Bacillus subtilis: A review. Afr. J. Agric. Res. 9:1265-1277.

Subba Rao, N. 1993. Biofertilizers in Agriculture and Forestry. Oxford and IBH Publishing Co., New Delhi, India.

Sukumar, P., Legué, V., Vayssières, A., Martin, F., Tuskan, G. A., and Kalluri, U. C. 2013. Involvement of auxin pathways in modulating root architecture during beneficial plant-microorganism interactions. Plant Cell Environ. 36:909-919.
Sung, K., and Chung, Y. 1997. Enhanced suppression of rice sheath blight using combination of bacteria which produce chitinases or antibiotics. Pages 370-372 in: Plant Growth-Promoting Rhizobacteria: Present Status and Future Prospects. A. Ogoshi, K. Kobayashi, Y. Homma, F. Kodama, N. Kondo, and S. Akino, eds. Faculty of Agriculture, Hokkaido University, Sapporo, Japan.

Vivekananthan, R., Ravi, M., Saravanakumar, D., Kumar, N., Prakasam, V., and Samiyappan, R. 2004. Microbially induced defense related proteins against postharvest anthracnose infection in mango. Crop Prot. 23:1061-1067.

Wang, X., Pan, Q., Chen, F., Yan, X., and Liao, H. 2011. Effects of co-inoculation with arbuscular mycorrhizal fungi and rhizobia on soybean growth as related to root architecture and availability of $\mathrm{N}$ and P. Mycorrhiza 21:173-181.

Xiang, N., Lawrence, K., Kloepper, J., Donald, P. A., and McInroy, J. 2017a. Biological control of Heterodera glycines by spore-forming plant growthpromoting rhizobacteria (PGPR) on soybean. PLoS One 12:e0181201.

Xiang, N., Lawrence, K. S., Kloepper, J. W., Donald, P. A., McInroy, J. A., and Lawrence, G. W. 2017b. Biological control of Meloidogyne incognita by spore-forming plant growth-promoting rhizobacteria on cotton. Plant Dis. 101:774-784.

Zhang, S., White, T. L., Martinez, M. C., McInroy, J. A., Kloepper, J. W., and Klassen, W. 2010. Evaluation of plant growth-promoting rhizobacteria for control of Phytophthora blight on squash under greenhouse conditions. Biol. Control 53:129-135.

Zhang, W., Jiang, F., and Ou, J. 2011. Global pesticide consumption and pollution: With China as a focus. Proc. Int. Acad. Ecol. Environ. Sci. 1:125-144. 